\title{
Dampak Program Simantri 245 Banteng Rene terhadap Subak Renon di Kecamatan Denpasar Selatan, Denpasar
}

\author{
AHMAD SURYA JAYA, I WAYAN WINDIA, \\ NYOMAN PARINING
}

\author{
Program Studi Agribisnis Fakultas Pertanian Universitas Udayana \\ Jl. PB. Sudirman 80323 Denpasar \\ Email: ahmadsuryajaya@gmail.com \\ wayanwindia@ymail.com
}

\begin{abstract}
Impact of 245 Rene Bull Simantri Program on Subak Renon in South Denpasar District, Denpasar
\end{abstract}

Simantri is one of the strategies in order to accelerate the adoption of agricultural technology by integrating the agricultural sector into supporting sectors in accordance with the potential of each region. The purpose of this study was to analyze and describe the impact of 245 Rene Bull Simantri program on Subak Renon Renon.

The choice of research location was made on purpose with consideration that the Subak location was within the urban areas. The existence of Simantri program in in Subak did not run well. Subak Renon which are adjacent to several other Simantri already capable of utilizing livestock waste into fertilizer. The 30 samples were taken out of 102 members of Subak, using a sampling technique of random sampling. The data were collected through interviews, observation and documentation. The data analysis used descriptive methods.

The results showed that there was no impact of 245 Simantri program on Subak Renon in terms of increased cropping intensity, the institutional development supporting agricultural activities, the increase of farmers' income, the area of organic lands, the creation and the development of organic agriculture and infrastructure in the region of Subak Renon, so that the activities of 245 Rene Bull Simantri Renon were inactivated. The suggestion that can be made by the writer associated with this study is that the government is expected to reactivate back 245 Rene Bull Simantri in Renon and the provincial and municipal governments are expected to provide competent assistance counselors and fund assistance in order to give a positive impact on Subak Renon.

Keywords: simantri, impact, agricultural activities, organic agriculture

\section{Pendahuluan}

\subsection{Latar Belakang}

Sektor pertanian di Bali merupakan sektor penyumbang pendapatan daerah terbesar kedua setelah sektor pariwisata (perdagangan, hotel, dan restoran). Berkembangnya pertanian di Bali didukung oleh dua organisasi pertanian besar yaitu subak dan simantri. Berdasarkan data Badan Perencanaan Pembangunan Pemerintah 
dan BPS Provinsi Bali (2014), pada tahun 2013 sektor pertanian mempunyai kontribusi yang besar terhadap Produk Domestik Regional Bruto (PDRB) Provinsi Bali, yaitu sebesar $16,82 \%$, sektor pariwisata sebesar $29,89 \%$, dan sisanya disumbangkan oleh sektor lainnya.

Simantri adalah upaya terobosan dalam mempercepat adopsi teknologi pertanian, karena merupakan pengembangan model percontohan dalam percepatan alih teknologi kepada masyarakat pedesaan. Simantri mengintegrasikan kegiatan sektor pertanian dengan sektor pendukungnya baik secara vertikal maupun horizontal sesuai potensi masing-masing wilayah dengan mengoptimalkan pemanfaatan sumberdaya lokal yang ada (Dinas Pertanian Tanaman Pangan, 2010).

Subak adalah suatu masyarakat hukum adat yang memiliki karakteristik sosioagraris-religius, yang merupakan perkumpulan petani yang mengelola air irigasi di lahan sawah. Selanjutnya Pusposutardjo (1997) dan Arif (1999), dalam Windia dkk (2005) yang meninjau subak sebagai sistem teknologi dari suatu sosiokultural masyarakat, menyimpulkan bahwa sistem irigasi (termasuk subak) merupakan suatu proses transformasi sistem kultural masyarakat yang pada dasarnya memiliki tiga subsistem yakni: (1). Subsistem budaya (pola pikir, norma dan nilai); (2). Subsistem sosial (termasuk ekonomi); dan (3). Subsistem kebendaan (termasuk teknologi). Semua subsistem itu memiliki hubungan timbal-balik, dan juga memiliki hubungan keseimbangan dengan lingkungannya.

Adanya dua organisasi petani yang ada dalam satu kawasan kerjaakan saling mempengaruhi. Simantri akan membawa dampak bagi organisasi yang telah ada salah satunya subak. Hal ini terjadi di kawasan Subak Renon yang di dalam kawasan tersebut terdapat Simantri 245. Simantri 245 Banteng Rene Renon yang berdekatan dengan Subak Renon telah mampu mengolah limbah menjadi pupuk organik, tetapi kondisi saat ini telah dinonaktifkan. Oleh karena itu perlu dikaji lebih dalam mengenai dampak program Simantri 245 Banteng Rene Renon terhadap Subak Renon.

\subsection{Rumusan Masalah}

Berdasarkan latar belakang di atas, maka permasalahan yang ingin dikaji dalam penelitian ini adalah apa dampak program Simantri 245 Banteng Rene terhadap Subak Renon ?

\subsection{Tujuan Penelitian}

Berdasarkan latar belakang dan rumusan masalah di atas, maka penelitian ini bertujuan menganalisis dan mendeskripsikan dampak program Simantri 245 Banteng Rene terhadap Subak Renon?

\section{Metode Penelitian}




\subsection{Lokasi dan Waktu Penelitian}

Penelitian ini dilaksanakan di Subak Renon, kawasan Kelurahan Renon, Kecamatan Denpasar Selatan, Kota Denpasar. Penelitian ini dilaksanakan pada bulan Mei sampai Juli 2016, di tempat yang telah disebutkan di atas.

\subsection{Penentuan Populasi dan Sampel}

Populasi adalah wilayah generalisasi terdiri atas obyek atau subyek yang mempunyai kualitas dan karakteristik tertentu yang selanjutnya ditetapkan oleh peneliti untuk dipelajari dan kemudian ditarik kesimpulan ( Sugiyono, 2008 dalam Anonim, 2016). Pada penelitian ini populasinya adalah semua anggota Subak Renon. Teknik pengambilan sampel pada penelitian ini menggunakan teknik random sampling. Jumlah sampel pada penelitian ini adalah 30 anggota subak, jumlah sampel yang dirasa cukup sehingga dapat diklaim mewakili populasi. Angka 30 merupakan pembatas untuk mengkategorikan jumlah sampel. Jika sampel > 30 maka kategorinya adalah sampel besar, jika < 30 kategorinya sampel kecil (Zebua, 2007).

\subsection{Teknik Pengumpulan Data, Variabel Penelitian dan Metode Analisis}

Metode pengumpulan data dilakukan dengan teknik wawancara, pengamatan, dan dokumentasi. Variabel pada penelitian ini adalah dampak program Simantri 245 Banteng Rene terhadap Subak Renon. Metode analisis yang digunakan pada penelitian ini adalah metode deskriptif.

\section{Hasil dan Pembahasan}

\subsection{Karakteristik Responden}

Karakteristik yang diamati dalam penelitian ini adalah jenis kelamin, umur, pendidikan, pekerjaan, luas lahan garapan, dan jumlah anggota keluarga.

\section{A. Jenis kelamin dan umur responden}

Karakteristik responden berdasarkan jenis kelamin pada penelitian ini adalah laki-laki sebanyak 100\%. Mantra (2003) dalam Ningtias (2016) menyatakan bahwa umur produktif secara ekonomi dibagi menjadi tiga klasifikasi, yaitu kelompok umur 0 s.d 14 tahun merupakan usia belum produktif, kelompok umur 15 s.d 64 tahun merupakan kelompok usia produktif, dan kelompok umur di atas 65 tahun merupakan kelompok usia tidak lagi produktif. Hasil penelitian menunjukkan bahwa $63 \%$ petani berada pada kisaran umur 15-64 tahun atau usia produktif dan sisanya 11\% brada pada kisaran umur diatas 64 tahun atau usia tidak produktif, hal ini menunjukan bahwa sebagian besar dari responden merupakan kelompok usia produktif.

\section{B. Tingkat pendidikan responden}

Seperti yang dinyatakan oleh Saridewi (2010), tingkat pendidikan seseorang dapat mengubah pola pikir, daya penalaran yang lebih baik, sehingga makin lama seseorang mengenyam pendidikan akan semakin rasional. Hasil penelitian menunjukkan bahwa pendidikan petani responden tergolong dalam kategori rendah yaitu 50\% berada pada kisaran nol s.d enam tahun yang setingkat tamatan sekolah 
dasar. Tingkatan tamatan SMP, D1, dan S1 masingmasing satu orang atau berkisar tiga persen, dan sisanya tidak sekolah yang berjumlah tujuh responden atau yang berkisar $23 \%$.

\section{Pekerjaan responden}

Hasil penelitian menunjukkan bahwa 28 atau $93 \%$ responden pekerjaan utamanya sebagai petani. Sisanya menjadikan bertani sebagai pekerjaan sampingan. Pekerjaan utama selain bertani yaitu pegawai di dinas pariwisata dan bekerja sebagai guru.

\section{Luas lahan responden}

Pradyani (2014) dalam Suardana (2015) mengemukakan bahwa, dengan luas lahan yang relatif sempit akan membuat petani kesulitan dalam mengembangkan usahataninya, pada akhirnya akan berpengaruh terhadap penerapan teknologi dan pendapatan yang diperoleh petani. Hasil penelitian menunjukkan bahwa semua lahan garapan responden tidak termasuk dalam kategori lahan garapan sempit. Sebagian besar responden memiliki luas lahan garapan sedang yaitu dari 30 responden, $80 \%$ responden memiliki luas lahan garapan yang berkisar diatas 0,5 s.d 1 ha. Sisanya yaitu 20\% responden memiliki luas lahan garapan dalam kategori luas yang berkisar diatas satu s.d dua ha.

\section{E. Jumlah anggota keluarga responden}

Hasil penelitan menunjukkan bahwa dari 30 responden memiliki jumlah tanggungan keluarga sebanyak dua sampai lima orang dalam satu kepala keluarga. Sebanyak $70 \%$ responden termasuk dalam kategori keluarga kecil, dan 30\% responden termasuk dalam kelompok kategori keluarga besar. Berdasarkan hasil penelitian, anggota keluarga responden sebagian tidak ikut bekerja di sawah. Anggota keluarga yang bekerja di sawah hanya kepala keluarga saja. Anggota keluarga yang lain mengerjakan pekerjaan yang lain di rumah.

\subsection{Dampak Program Simantri Terhadap Subak Renon}

\section{A. Dampak Terhadap Peningkatan Intensitas Tanam}

Hasil penelitian menunjukkan luas tanam anggota Subak Renon pada musim tanam pertama dan kedua sebelum dan setelah ada simantri tidak terlalu mengalami perubahan luas tanam. Setelah ada simantri dari 30 responden, hanya tiga responden yang mengalami perubahan luas tanam. Ketiga responden yang mengalami perubahan luas tanam dua diantaranya mengalami penurunan luas tanam. Sebelum ada simantri luas tanam 12 are dan 80 are tetapi setelah ada simantri luas tanam berkurang menjadi enam are dan 30 are. Satu responden lainnya mengalami peningkatan luas tanam yaitu dari 100 are menjadi 135 are. Intensitas tanam pada Subak Renon dari musim tanam satu dan dua selalu memanfaatkan $100 \%$ lahannya untuk bercocok tanam tanpa ada lahan yang disisakan. Total intensitas tanam petani pada Subak Renon selama satu tahun yaitu $200 \%$ sebelum dan setelah ada siamntri. Dari data di atas terlihat tidak ada dampak Simantri 245 Banteng Rene Renon terhadap Subak Renon, dalam hal peningkatan intensitas tanam. 


\section{B. Dampak Terhadap Berkembangnya Kelembagaan Pendukung Kegiatan Pertanian}

Menurut ketua Subak Renon, Lembaga Keuangan Mikro Agribisnis (LKMA) adalah satu-satunya lembaga pertanian yang terbentuk setelah adanya simantri yaitu pada tahun 2014 awal. Terbentuknya LKMA di kawasan Subak Renon tidak diakibatkan oleh adanya Simantri 245 Banteng Rene Renon. Jadi, tidak ada dampak program Simantri 245 Banteng Rene Renon terhadap berkembangnya lembaga pendukung kegiatan pertanian di kawasan Subak Renon.

\section{Dampak Terhadap Peningkatan Pendapatan Petani}

Jhingan (2003) dalam Anonim (a) (2016) menyatakan bahwa pendapatan adalah penghasilan berupa uang selama periode tertentu. Pendapatan menunjukkan seluruh uang atau hasil material lainnya yang dicapai dari penggunaan kekayaan atau jasa yang diterima oleh seseorang atau rumah tangga selama jangka waktu tertentu pada suatu kegiatan ekonomi (Winardi, 1998 dalam Anonim (b), 2016). Pendapatan yang diukur disini adalah pendapatan satu tahun sebelum ada simantri dan pendapatan satu tahun setelah ada simantri. Pengukurannya yang digunakan adalah paired sample t test yaitu Uji ini digunakan untuk mengetahui ada atau tidaknya perbedaan antara dua kelompok sampel yang berpasangan (berhubungan). Maksudnya disini adalah sebuah sampel tetapi mengalami dua perlakuan yang berbeda. Paired sampel statistik adalah uji yang dilakukan untuk mengetahui perbedaan rata-rata pada sebuah sampel yang mengalami perlakuan yang berbeda, untuk lebih jelasnya dapat dilihat pada Tabel 1 .

Tabel 1.

Pairet Sampel Statistik

\begin{tabular}{lccccc}
\hline & & Mean & N & Std. Deviation & Std. Error Mean \\
\hline Pair 1 & VAR00001 & 27334955.0000 & 30 & 18534222.62690 & 3383870.60619 \\
& VAR00002 & 26448915.0000 & 30 & 18708587.39139 & 3415705.11111 \\
\hline
\end{tabular}

Tabel 1 menunjukkan rata-rata pendapatan petani dari usahata tani sebelum dan setelah ada simantri. Sebelum ada simantri rata-rata pendapatan petani dari usaha tani sebesar Rp 27.334.955, per dua kali musim tanam, sementara setelah ada simantri rata-rata pendapatan petani dari usaha tani adalah sebesar Rp 26.448.915 per dua kali musim tanam. Paired Samles test adalah test untuk mengetahui signifikan atau tidaknya perbedaan yang terjadi dari dampak keberadaan simantri terhadap pendapatan petani anggota Subak Renon dapat dilihat pada Tabel 2. 
Tabel 2.

Paired Samples Test

\begin{tabular}{|c|c|c|c|c|c|c|c|c|c|}
\hline & & \multicolumn{5}{|c|}{ Paired Differences } & \multirow[b]{3}{*}{$\mathrm{t}$} & \multirow[b]{3}{*}{ df } & \multirow{3}{*}{$\begin{array}{l}\text { Sig. ( } 2- \\
\text { tailed) }\end{array}$} \\
\hline & & \multirow[b]{2}{*}{ Mean } & \multirow{2}{*}{$\begin{array}{l}\text { Std. } \\
\text { Deviation }\end{array}$} & \multirow{2}{*}{$\begin{array}{l}\text { Std. Error } \\
\text { Mean }\end{array}$} & \multicolumn{2}{|c|}{$\begin{array}{c}95 \% \text { Confidence Interval } \\
\text { of the Difference }\end{array}$} & & & \\
\hline & & & & & Lower & Upper & & & \\
\hline Pair 1 & $\begin{array}{l}\text { VAR00001 - } \\
\text { VAR00002 }\end{array}$ & 886040.00 & 4234483.90 & 773107.45 & -695142.27 & 2467222.27 & 1.146 & 29 & .261 \\
\hline
\end{tabular}

Tabel 2 menunjukan nilai thitung adalah sebesar 1.146 degan sig 0.261. Karena sig > 0.05 maka dapat disimpulkan bahwa rata-rata pendapatan petani dari usahatani sebelum dan setelah ada simantri adalah sama (tidak berbeda). Hasil data di atas dapat dinyatakan bahwa program simantri tidak berdampak terhadap pendapatan petani dari usahatani.

\section{Dampak terhadap luas lahan organik}

Hasil penlitian menunjukkan di Subak Renon sebelum ada simantri dari luas lahan subak 90 ha belum pernah menggunakan pupuk organik untuk bertani. Penggunaan pupuk organik hanya tahap uji coba pada sebagin lahan garapan petani, percobaan dilakukan pada 10 anggota simantri dengan luas lahan sekitar 357 are. Percobaan tersebut gagal karena tanaman padi petani memerah setelah menggunakan pupuk organik, sehingga para petani kembali menggunakan pupuk nonorganik. Hasil data di atas dapat dinyatakan bahwa tidak ada dampak program Simantri 245 Banteng Rene Renon terhadap Subak Renon dalam hal peningakatan luas lahan organik.

\section{E. Dampak Terhadap Tercipta dan Berkembangnya Pertanian Organik}

Makin meningkatnya jumlah konsumen produksi bersih dan meningkatnya serta meluasnya gerakan green consumer merupakan pendorong segera disosialisasikan gerakan pertanian organik (Sutanto, 2002 dalam Hutagoal, 2015). Hasil penelitian menunjukan dari 30 responden belum ada yang menggunakan pupuk organik untuk bertani, sebelum dan setelah ada simantri. Sebelum ada simantri para petani sudah akrab dengan pupuk nonorganik.

\section{F. Dampak terhadap Berkembangnya Infrastruktur di Kawasan Subak Renon}

Hasil penelitian menunjukkan bahwa kondisi imfrastruktur di kawasan Subak Renon sebagian besar jalan di sekitar subak sudah bagus, keadaan ini disebabkan banyaknya bangunan perumahan di sekitar sawah. Menurut ketua Subak Renon, jalan yang ada sekarang ini sudah ada sebelum ada simantri.

\section{G. Dampak terhadap Konflik Kepentingan Air}

Hasil penelitian menunjukkan antara subak dan simantri tidak pernah terjadi konflik kepentingan air. Menurut ketua Subak Renon anggota simantri dan anggota subak tidak pernah terjadi konflik merebutkan air. Semua bisa berjalan dengan berdampingan. Air yang mengalir dari Sungai Ayung dibagi dengan Subak Sanur. Pembagian dilakukan setiap tahun secara bergiliran. 


\section{H. Dampak terhadap Konflik Pola Tanam}

Dari hasil penelitian, konflik pola tanam di Subak Renon bisa diatasi. Hal itu dikarenakan jadwal tanam sudah disepakati oleh seluruh anggota subak maupun anggota simantri yang sekaligus anggota subak untuk lebih jelasnya terdapat pada Tabel 3. Dari data di atas dapat dinyatakan setelah keberadaan simantri tidak pernah menimbulkan konflik kepentingan air antara Simantri 245 Banteng Rene Renon dengan Subak Renon.

Tabel 3.

Sistem Pola Tanam Subak Renon

\begin{tabular}{cll}
\hline No & Tahun & \multicolumn{1}{c}{ Pola tanam } \\
\hline 1 & Genap & Padi, padi, padi \\
2 & Ganjil & Padi, padi, palawija \\
\hline
\end{tabular}

Sumber: Pagiarta (2016).

Tabel 3 menunjukkan pola tanam pada Subak Renon yaitu pada tahun genap dilakukan pola tanam padi, padi, padi. Pada tahun ganjil dilakukan dengan pola tanam padi, padi, palawija. Penerapan sistem pola tanam seperti ini para petani dapat menanam padi satu tahun tiga kali padi pada tahun genap dan tahun ganjil menanam palawija satu kali untuk memutus rantai makanan hama. Hasil data di atas dapat dinyatakan setelah keberadaan simantri tidak pernah menimbulkan konflik pola tanam antara Simantri 245 Banteng Rene Renon dengan Subak Renon.

\section{Simpulan dan saran}

Berdasarkan hasil penelitian, dapat disimpulkan bahwa analisis dan deskripsi dampak program Simantri 245 Banteng Rene terhadap Subak Renon adalah tidak ada dampak program Simantri 245 terhadap Subak Renon dalam hal peningkatan intensitas tanam, perkembangan kelembagaan pendukung kegiatan pertanian, peningkatan pendapatan petani, luas lahan organik, tercipta dan berkembangnya pertanian organik, dan infrastruktur di kawasan Subak Renon. Kegiatan Simantri 245 Banteng Rene Renon pada saat ini masih dinonaktivkan karena permasalahan tersebut.

Sesuai dengan hasil kesimpulan penelitian dampak program Simantri 245 Banteng Rene Renon terhadap Subak Renon maka disarankan hal-hal sebagai berikut 1. Pemerintah provinsi diharapkan mengaktifkan kembali aktivitas kegiatan Simantri 245 Banteng Rene Renon, agar kegiatan simantri berdampak pada berkembangnya lembaga pendukung kegiatan pertanian, peningkatan intensitas tanam, peningkatan pendapatan petani, peningkatan luas lahan organik, tercipta dan berkembangnya pertanian organik, dan berkembangnya infrastruktur di kawasan Subak Renon.

2. Memberikan bantuan tenaga penyuluh atau pendamping yang kompeten dan bantuan dana selain dari pemerintah provinsi seperti pemerintah kota sangat 
diharapkan. Dengan demikian diharapkan simantri mampu menjalankan dan mengoperasikan kegiatan-kegiatannya dengan baik sehingga dapat memberikan dampak positif pada subak di kawasan tersebut.

\section{Daftar Pustaka}

Anonim (a). 2016. Landasan Teori Pendapatan Petani. Tersedia: digilib.unila.ac.id (diunduh tanggal 12 Mei 2016).

Anonim (b). 2016. BAB III Objek dan Metodelogi Penelitian. Tersedia: dir.unikom.ac.id (diunduh tanggal 15 mei 2016).

Badan Pusat Statistik (BPS) Provinsi Bali (2014). Produk Domestik Regional Bruto.Tersedia: http://bali.bps.go.id (diunduh tanggal 5 Februari 2016)

Dinas Pertanian Tanaman Pangan Provinsi Bali, 2010. Kegiatan Sistem Pertanian Terintegrasi (Simantri) di Provinsi Bali. Tersedia: www.baliprov.go.id. (di unduh tanggal 5 Februari 2016).

Hutagaol. 2015. BAB III Tinjauan Pustaka Pengertian Pertanian Organik. Tersedia: repository.usu.ac.id. (dinduh tanggal 12 Mei 2016).

Ningtias, Rista Ayu. 2016. Tingkat Adopsi Sistem Jajar Legowo 2:1di Kelompok Tani Mina Sri Jaya Desa Sepanjang Kecamatan Glenmore Kabupaten Banyuwangi Jawa Timur. Ph. D. Skripsi. Universitas Udayana.

Saridewi, Ratna dan Amelia Nani Siregar. 2010. Hubungan Antara Peran Penyuluh dan Adopsi Teknologi Oleh Petani Terhadap Peningkatan Produksi Padi di Kabupaten Tasikmalaya. Tersedia: www.stpp-bogor.ac.id. (diunduh tanggal 12 Mei 2016).

Suardane, Komang Eke. 2015. Partisipasi Petani dalam Pengembangan Program Hutan Rakyat di Dusun Talang Gunung Desa Talang Batu Kecamatan Mesuji Timur Kabupaten Mesuji Provinsi Lampung. Ph. D. Skripsi. Universitas Udayana.

Windia, Wayan. 2005. Sistem Irigasi Subak dengan Landasan Tri Hita Karana (Thk) Sebagai Teknologi Sepadan dalam Pertanian Beririgasil. Tersedia: download.portalgaruda.org. (di unduh tanggal 28 Februari 2016).

Zebua, 2007. Sampel Penelitian. Tersedia: http://researchexpert.wordpress.com. (diunduh tanggal 25 Mei 2016). 